\title{
Stigma i internasjonal politiklk: Norge, EU og søken etter «det normale» $i$ en post-sovjetisk silkerhetskontekst
}

ØYVIND SVENDSEN*, MSc, Lektor, Høgskolen i Lillehammer, Vinner av Ordingprisen 2015

Hvorfor er det slik at Norge er blitt en aktiv aktør i EUs sikkerhetspolitikk? Denne artikkelen tar tak i det som tilsynelatende er en anomali i Norges forhold til EU etter 1990: på den ene siden er landet ikke medlem i EU, på den andre siden har det siden Sovjetunionen falt vært søkt stadig tettere sikkerhetspolitiske bånd med unionen. Sanksjonsregimet som ble innført mot Russland etter annekteringen av Krim-halvøya er et eksempel på dette. Ved å anvende sosialteori fra Pierre Bourdieu og Erving Goffman slik Rebecca Adler-Nissen har behandlet dem begge i fagfeltet IR, argumenterer jeg for at konvergenspraksisen som har utviklet seg mellom Norge og EU har vært drevet frem av (1) de norske eliters integrasjonsvennlige habitus, (2) EUs symbolmakt i forholdet med Norge og (3) en stigmatiseringsprosess i det europeiske sikkerhetsfeltet. Det siste vektlegges i særlig grad, og går ut på at norske aktører er ukomfortable med å bli sett på som «outsidere» i Europa. Responsen har vært anerkjennelse av stigmaet i et ønske om å fremstå som «normal».

Nøkkelord: Sikkerhetspolitikk • sosialteori • stigma • makt • integrasjon • Norge • EU

Why has Norway developed to become an active agent in EU security policy? This article questions an apparent anomaly in Norway's relationship with the EU since 1990: on the one side the country is not a member of the union, on the other, it has sought close ties in with the EU in relation to security since the Soviet Union fell. The sanctioning regime following Russia's annexation of the Crimean peninsula is a recent example of this. By utilising the insights of social theorists Pierre Bourdieu and Erving Goffman, as brought into IR by Rebecca Adler-Nissen, I argue that the practice of convergence was, and is, driven by (1) the integrationist habitus of Norwegian elites, (2) The EUs symbolic power in its relationship with Norway and (3) a process of stigmatization in the European field of security. The latter point is treated with particular attention, and involves how Norwegian actors finds it uncomfortable to be «outsiders» in

^Korrespondanse: Øyvind Svendsen, MSc, Lektor, Høgskolen i Lillehammer, Vinner av Ordingprisen 2015. Email: oyvind.svendsen@hil.no 
Europe. The response has been stigma recognition in an attempt to pass as «normal».

Keywords: security policy - social theory - stigma - power • integration • Norway • EU

\section{Innledning}

Hvorfor er det slik at Norge som har valgt å stå utenfor den Europeiske Union (EU) likevel er en aktiv deltaker i unionens sikkerhetspolitikk? Denne artikkelen diskuterer det som tilsynelatende er en anomali i Norges forhold til EU i sikkerhetspolitikken: på den ene siden er landet ikke medlem i EU, på den andre siden har det siden Sovjetunionen falt søkt stadig tettere bånd med unionen på det sikkerhetspolitiske feltet. Sanksjonsregimet som ble innført mot Russland etter annekteringen av Krimhalvøya er et illustrerende eksempel. Norge innførte EUs sanksjoner mot Russland uten særlig debatt hjemme og avgjørelsen ble av Utenriksminister Børge Brende begrunnet med at «det har vært tradisjon i Norge gjennom vekslende regjeringer for å følge EU i slike spørsmål. Det gjorde vi i forrige runde, og det vil vi gjøre nå» (sitert i Dagbladet 2014). Brende hadde rett i å vise til tradisjonen - praksisen med å følge EU i bruken av sanksjoner har vært brukt mot Burma, Hviterussland, Iran, Syria og Libya, i tillegg til Russland (Sverdrup 2014).

Helene Sjursen har i flere arbeid vist hvordan Norge har søkt tette bånd med EUs felles utenriks- og sikkerhetspolitikk (FUSP) (se f.eks. Sjursen 2004). I en fersk kritikk av konsensuslinjen i norsk utenrikspolitikk påpeker hun hvor villige norske myndigheter har vært til å følge EU i sikkerhetspolitikken. Det er rutine å slutte seg til de fleste av EUs erklæringer og posisjoner, Norge bidrar som oftest til krisehåndteringsoperasjoner når invitasjon foreligger, Norge har meldt sivile og militære styrker inn i EUs styrkeregister og Norge er med på prosjekter gjennom EUs forsvarsbyrå, European Defence Agency (EDA) (Sjursen 2015: 222). Dette skjer altså til tross for at det norske folk har takket nei til medlemskap i EU ved to anledninger, i 1972 og 1994. Norge er heller ikke bundet til EUs sikkerhetspolitikk gjennom EØS-avtalen, spesielt ikke i et slikt omfang som det har utviklet seg til. Noen få andre bilaterale avtaler er inngått mellom Norge og EU på sikkerhetsfeltet, men også de i tiden etter 1990 (NOU 2012: 2). Heller ikke disse avtalene har lagt direkte til rette for de praksisene som har utviklet seg. På bakgrunn av dette burde tendensen der Norge rutinemessig følger EU-linjen i sikkerhetspolitikken være av interesse. Hvordan kan vi forstå en liten stats sikkerhetspolitiske veivalg på et kontinent der de fleste andre står på innsiden av en mektig organisasjon som EU?

Denne artikkelen introduserer et sosialteoretisk rammeverk for å forstå hvorfor Norge som en selv-ekskludert europeisk stat likevel fortsetter integrasjonen med EU på det sikkerhetspolitiske feltet. Mye av det som skrives om norsk utenrikspolitikk baserer seg på en forståelse av aktører som kost-nyttetenkende og rasjonelle. Jeg vil her fokusere på hvordan makt opererer underbevisst og produserer de identiteter og 
interesser som oppfattes som «norske». Det er nettopp spenningsforholdet mellom Norge som frivillig utenforland og samtidig velvillig bidragsyter til EU i sikkerhetspolitikken som er utgangspunktet for artikkelen. Norges sosialisering inn i det europeiske sikkerhetsfeltet og EUs dominerende posisjon i det samme feltet setter også søkelys på opinionens betydning i det moderne demokrati. Gitt det overveldende flertallet mot medlemskap $\mathrm{i}$ den norske befolkningen er det potensielt problematisk at norske regjeringer fortsetter integrasjonen med EU. ${ }^{1}$

Jeg vil i det følgende peke på en del svakheter ved rasjonalistiske forklaringsmodeller og foreslå en praksistilnærming til studiet av staters sikkerhetspolitikk. Denne tilnærmingen fokuserer på sosialisering og ulike maktforhold som konstituerende for utformingen av sikkerhetspolitikk. Mitt argument er at norske aktører i sikkerhetspolitikken har vært så positive til EU at de har vært tilbakeholdne med å gå inn i politiske maktkamper med EU om utformingen av europeisk sikkerhetspolitikk etter den kalde krigen. Disse norske aktørene er tvunget av befolkningen til å stå utenfor EU-samarbeidet, samtidig som de selv helst ser at Norge blir med i unionen. Fordi norske sikkerhetspolitiske aktører ønsker å oppfattes som normale og unngå sosialt stigma, har de benyttet sine mandater til å utforme en politikk der Norge fremstår akkurat som EU-landene i sikkerhetspolitikken. I det følgende vil jeg gjennomgå noen sentrale forskningsbidrag om Norge og EU i sikkerhetspolitikken og kritisere dem på bakgrunn av handlingslogikkene de tilskriver aktører i internasjonal politikk. Videre vil jeg foreslå et teoretisk rammeverk motivert av sosialteoriens stadig voksende rolle innenfor fagfeltet International Relations (IR) siden midten av 2000-tallet. Jeg vil trekke på den franske sosiologen Pierre Bourdieu i et forsøk på å fange opp hvordan det sosiale i seg selv er basert på maktforhold, samt på Erving Goffmans arbeid med stigma for å utfordre oppfatningen av sosialisering som noe utelukkende frivillig og rasjonelt. Rebecca Adler-Nissens (2013; 2014a; 2014b) arbeid med begge disse teoretikerne står helt sentralt i artikkelens teoretiske rammeverk. Den påfølgende analysen vil anvende denne sosialteoretiske praksistilnærmingen til å redefinere vår forståelse av hvordan Norges utenrikspolitiske interesser har vokst fram $i$ relasjon til EU i en post-sovjetisk sikkerhetskontekst.

\section{Rasjonalitet i utenriks- og sikkerhetspolitikk}

Sikkerhetsdynamikken slik den har utviklet seg mellom Norge og EU er ikke studert i stor grad og i enda mindre grad kritisert. De tilnærmingene jeg vil vise til her føyer seg tilsynelatende i rekken av studier som behandler EU som en universelt attraktiv organisasjon som besitter evnen til å definere hva som forstås som «normal» oppførsel

\footnotetext{
${ }^{1}$ På tross av dette er ikke denne artikkelen ment som noen kritikk av Norges sikkerhetspolitikk som sådan. Det finnes mange argumenter for at Norge og EU tilhører det samme sikkerhetsfelleskapet (Adler \& Barnett 1998) og at samordning av sikkerhetspolitikken har mange fordeler. Den underliggende motivasjonen her er heller å presentere en versjon av utviklingen i norsk sikkerhetspolitikk de siste 25 årene som tar på alvor sosiale forhold og hvordan dynamikkene i dem er sentrale i artikuleringen av Norges interesser.
} 
innenfor utenriks- og sikkerhetspolitikk (Manners 2002). Allerede nevnte Sjursen (2008) har for eksempel sett på hvordan den offentlige debatten rundt europeisk integrasjon har vært basert på norske politikeres oppfattede forpliktelser overfor det internasjonale samfunnet. Pernille Rieker (2004; 2006) foreslår tre komplementære forklaringer: den nasjonale sikkerhetsinteressen, diplomatielitens ønske om å være med i «EU-klubben» og den samme elitens gradvise «europeisering».

De overnevnte studiene av Norges interesser i sikkerhetspolitikken er ikke basert på statiske forståelser av den nasjonale interesse som en fullstendig definerbar størrelse som er basert på materielle sikkerhetshensyn. Tvert i mot går de langt i å vektlegge hvordan ulike aktørers ideer om europeisk identitet former det som kollektivt blir til «den nasjonale interesse». De er altså viktige analyser av Norges sikkerhetspolitiske forhold til EU etter Sovjetunionens fall som fokuserer på moralske forpliktelser, tradisjonelle sikkerhetsinteresser og politiske eliters rolle i definisjonen av sikkerhet. Problemet med begge tilnærmingene er imidlertid at de langt på vei baserer seg på en rasjonalistisk ontologi der ideer og identiteter behandles som kognitive instrumenter som definerer norske sikkerhetsinteresser og fungerer som veikart i utviklingen av sikkerhetspolitikken (Goldstein \& Keohane 1993). Slik sitter man igjen med en forståelse av norsk utenrikspolitikk som tar utgangspunkt i en blanding av ulike handlingslogikker basert på konsekvenstenkning, hva som oppfattes som passende og hva man kommer til gjennom diskusjon av habermasiansk art (March \& Olsen 1998; Risse 2000).

Mitt argument er at et for ensidig fokus på disse formene for rasjonalitet er utilstrekkelig - ingen studier av Norges sikkerhetspolitiske EU-linje har for alvor tatt for seg hva som former tenkningen omkring hva som forstås som passende, rett eller de potensielle konsekvensene av handlinger. Det er behov for å utvikle perspektiver som tar høyde for de sosiale forholdene som bidrar til dannelsen av en 'norsk' forståelse av sikkerhet i Europa i dag. Vi må forbi den rasjonalistiske forståelsen av norske sikkerhetsinteresser som basert på en nasjonal interesse forstått som løsrevet fra de sosiale rammene til de menneskene som utformer sikkerhetspolitikken. Ved å anlegge et slikt perspektiv muliggjøres en analyse av det vi ikke snakker om - den praktiske kunnskapen som gjør at det som skal gjøres fremstår som selvinnlysende, eller som den rette tingen å gjøre (Pouliot 2008; Stuvøy 2010). Dette finner vi hos Bourdieu i begrepet habitus, definert som et system av strukturerte, strukturerende disposisjoner som fungerer som prinsipper som skaper og organiserer praksiser og representasjoner uten at det nødvendigvis ligger noen spesielle ferdigheter bak (Bourdieu 1990: 52-53). Fra denne posisjonen bør handlinger i det sosiale ikke forklares ut ifra utilitaristiske kalkuleringsmodeller, men fra internaliserte erfaringer som legger føringer for politiske praksiser (Stuvøy 2009: 161).

Ved å trekke veksler på den såkalte 'practice turn' i IR (se f.eks. Neumann 2002; Adler \& Pouliot 2011; Adler-Nissen 2016), bygger denne analysen på Bourdieus sosialteori og teoretiserer et sikkerhetsfelt der aktører inngår i maktkamper over definisjonen av den legitime tilnærmingen til sikkerhet. Bourdianske sikkerhetsstudier blir i stadig større grad anvendt i forskningen på europeisk sikkerhet (se Mérand 2010; Villumsen Berling 2012; Adler-Nissen 2013). Sentralt i denne typen studier står ideen om at «symbolic relations of power tend to reproduce and to reinforce the 
power relations that constitute the structure of social space» (Bourdieu 1989: 21). Disse maktrelasjonene er sentrale for å forstå anomalien som ligger til grunn her: hvorfor følger ikke-medlemmet Norge EU i sikkerhetspolitikken?

Forestillingen om at symbolsk makt bestemmer aktørers posisjoner og strategier i det sosiale liv, sammen med den fremvoksende praksisen der Norge følger EU i sikkerhetspolitikken, åpner også opp for videre teoretisering av symbolmaktens konsekvenser. Norge kunne om ønskelig inntatt en annen posisjon i det europeiske sikkerhetsfeltet enn hva en gjør i dag og har gjort de siste 25 årene. Norges valg av posisjon derimot, er strukturert av maktrelasjoner som er definert gjennom landets stilling som utenforstående i europeisk politikk. Denne dynamikken skal her forstås gjennom et fokus på stigmatisering (Adler Nissen 2014a). EUs symbolmakt i det europeiske sikkerhetsfeltet har ført til at Norge har blitt stigmatisert som en «outsider» og dette har fra Norges side blitt møtt med strategien stigma-anerkjennelse. Norge har altså beveget seg i retning av konvergens med EU i sikkerhetspolitikken fordi stigmaet som utenforstående passer dårlig for norske aktører som gjerne skulle sett at Norge sto på innsiden av integrasjonsprosessen. Grunnet EUs symbolmakt og norske aktørers ønske om å fremstå som «normale» i det europeiske sikkerhetsfeltet, er det EU som har makten til å definere hva som er «rett» eller «normalt» å gjøre med hensyn til sikkerhetsspørsmål.

\section{A teoretisere sikkerhet i IR: en relasjonell tilnarming}

En sosial tilnærming til spørsmålet som stilles i denne artikkelen krever et intersubjektivt og relasjonelt perspektiv. Her vil ikke analyseverktøyene som finnes i klassisk IR-teori (strukturelt orienterte og rasjonalistiske forklaringsmodeller) kunne bidra i særlig grad. Tradisjonelt har faget operert med ulike ontologier som fokuserer på internasjonalt og ikke-hierarkisk anarki der stater balanserer hverandre basert på materielle interesser og tvingende nødvendige sikkerhetsdilemmaer (se Waltz 1979; Walt 1991). Andre har fokusert på forutsetningene for samarbeid (se Nye \& Keohane 1977; Axelrod \& Keohane 1985; Doyle 1986), mens den opprinnelige sosialkonstruktivismen innenfor faget fokuserte på hvordan aktører og strukturer former hverandre og at globale strukturer er foranderlige (Wendt 1987; 1992). Dessverre ble denne konstruktivismen for opptatt av systemets stabilitet og mistet noe av sitt potensiale som sosialt reflektert (se Wendt 1999).

Mer lovende i så henseende er teoriskolen som vokste frem i København mot slutten av 1990-tallet. Denne tilnærmingen til sikkerhet rommer intersubjektivitet i begrepet «sikkerhetisering» som ser sikkerhet som et praksisfelt (Wæver 1995: 50). Her handler sikkerhet om "who can 'do' or 'speak' security successfully, on what issues, under what conditions, and with what effects» (Buzan et al. 1998: 27). Objektene som skal sikres er ikke asosiale strukturer, men individer som er i stand til å kommunisere, eller «sikkerhetisere», sine samfunnsutfordringer. Københavnerskolen ble meget populær etter sin såkalte konstruktivistiske vending som åpnet for studier av kampene som skaper våre forståelser av hva sikkerhet er (Eriksson 1999: 314). Jeg støtter langt på vei dette, men synes Københavnerskolens antakelse om at 
sikkerhet faktisk blir kommunisert er problematisk (Hansen 2000). I denne artikkelens kontekst blir dette tydelig fordi Norge forventes å kunne uttrykke sine betraktninger omkring sikkerhet, men en slik tilnærming vil potensielt være blind for det som forblir usagt, de ontologisk eksisterende strukturene som ikke blir gjenstand for diskusjon.

Det er denne mangelen som åpner opp et rom for Bourdieus sosiale teori. Den tillater oss å løfte blikket opp fra asosial statssentrisme, sette fokuset på praksiser og konstruere sosiale felter induktivt ved å se på aktører og hvordan deres kapabiliteter og tilbøyeligheter strukturerer felter omkring forskjellige kontroverser. For Trine Villumsen Berling (2015: 29), har denne kontroversen i Europa siden 1990 handlet om å ha makten til å definere hva som bør være den legitime tilnærmingen til sikkerhet på kontinentet. Den politiske kampen som strukturerer staters sikkerhetsinteresser er dermed en kamp over hva man skal være usikker på i utgangspunktet. Makt behandles her relasjonelt og som konstituerende - det er ikke kun tale om staters materielle kapabiliteter, men makt er definert i en kontekst der det eksisterer «objective structures independent of the consciousness and will of agents, which are capable of guiding and constraining their practices or their representations» (Bourdieu 1989: 14).

Denne analysen vil trekke veksler på det som har blitt hevdet å være Bourdieus tre mest sentrale begreper: felt, symbolmakt og habitus (Swartz 2008). Videre er det noe spesielt med Norges rolle innenfor Europas grenser, men utenfor EU som tilsier en spesiell status $\mathrm{i}$ analysen. Adler-Nissen (2013: 4) har hevdet at distinksjonen mellom «innenfor» og «utenfor» slik den forstås i Den engelske skolen i IR-faget, ville bli forstått annerledes av Bourdieu. Han ville ikke sett på dette som en distinksjon overhodet, men som et utrykk for hvordan eksklusjonsprosesser er iboende i det internasjonale samfunnet. Derfor er det viktig å ta høyde for Norges posisjon i en «skvis» i europeisk sikkerhetspolitikk. Det er ikke bare symbolmakt og ulike tilbøyeligheter som bidrar i kampen om usikkerheten, men også et dyptliggende stigma som anvendes instrumentelt mot norske aktører i sikkerhetsfeltet. Dette skyldes at Norge oppfattes som en «outsider», og svaret fra norske myndigheters side har vært å anerkjenne dette stigmaet fordi de ønsker å fremstå som «normale» i det europeiske sikkerhetsfeltet. Denne analysen tar på alvor de fordelene ulike aktører har, basert på hierarkisk ordnet symbolmakt som tillater deres syn og posisjoner å bli naturalisert og anerkjent. Norge er ikke nødvendigvis en rasjonell aktør i internasjonal politikk som definerer sine sikkerhetsinteresser frigjort fra en sosial setting. I stedet spiller maktforhold en sentral rolle, og i de politiske maktkampene omkring europeisk sikkerhet siden 1990 har ikke Norge vært noen spesielt selvstendig aktør.

Feltet

Stedet der politiske maktkamper foregår er feltet, et av Bourdieus analytiske begrep. Guzzini (2000) skriver: «Fields correspond to a network of positions, a set of interactions with a shared system of meaning. They give meaning to agency. They are the playground where agents realize individual strategies, playing within, and thereby openly reducing, the rules of a given game». Internasjonal politikk struktureres også 
av nettverk av posisjoner, og utviklingen av norsk sikkerhetspolitikk etter 1990 bør kunne utforskes fra et analytisk felt som struktureres av kampen om den legitime tilnærmingen til (u)sikkerhet i Europa (Villumsen Berling 2015).

Det europeiske sikkerhetsfeltet består altså ikke av grenser i betydningen institusjonelle bindinger eller statsgrenser. I stedet opererer det på en magnetisk måte ved å tiltrekke seg aktører som tar plass i maktkampen om hva som bør være den legitime tilnærmingen til (u)sikkerhet i Europa (Bigo \& Walker 2007: 732). Dette gir analysen to fordeler. For det første tillater det analysen å behandle den mellomstatlige organisasjonen EU som en aktør. Den andre og mer viktige fordelen er at det leder analysen inn i en undersøkelse av den posisjonen Norge tar i kampen for å definere sikkerhet. Når felter struktureres kan aktører ta opp ortodokse eller heterodokse posisjoner, og da Sovjetunionen falt endret også betydningen av de to ulike posisjonene seg (Villumsen Berling 2012: 452). Den norske holdningen til sikkerhet etter $1990 \mathrm{kan}$, slik den fremstilles her, forstås som at landet har tatt en ortodoks posisjon i feltet og adoptert heller enn å definert den nye sikkerhetsforståelsen i Europa. Det europeiske sikkerhetsfeltet slik det er utviklet i denne artikkelen bør derfor ikke være gjenstand for videre definisjon basert på empirisk forskning, men kan anvendes som det området der maktkampen har, eller ikke har, funnet sted på vei mot definisjonen av en ny normal i sikkerhetspolitikken. Mer interessant er de strukturerende dynamikkene mellom aktørene i et bredt forstått europeisk sikkerhetsfelt som har bidratt til naturaliseringen av EUs sikkerhetspolitiske rolle.

\section{Habitus}

Norske eliter står i sterk opposisjon til befolkningen for øvrig når det kommer til europeisk identitet og forbrødring (Archer 2005). Dermed kan det hevdes at når det kommer til eliter i Norge, så tar «the dispositions of agents, their habitus, (...) the mental structures through which they apprehend the social world» (Bourdieu 1989: 18), form som støtte til EU. Dette begrenser i neste omgang deres vilje og evne til å innta en opposisjonell posisjon i politiske maktkamper med Brussel. I studiet av Norges posisjonstaking innenfor det sikkerhetspolitiske feltet er altså, i tråd med Bourdieu, «the most crucial thing to note (...) that the question of this space is raised within the space itself - that the agents have points of view on this objective space which depend on their position within it and in which their will to transform or conserve it is often expressed» (Bourdieu 1984: 169).

Aktører tar del i mange felter gjennom sine liv og en persons habitus er derfor ikke stabil, men gjenstand for endring over tid (Leander 2008: 17). Aktørers tilbøyeligheter har også sitt utspring fra de sosiale strukturene de befinner seg i. Gitt observasjonen av et skille mellom eliter og befolkningen i EU-spørsmålet, og at de som opererer på vegne av Norge i utenriks- og sikkerhetspolitikken gjerne tilhører de høyere klasser, kan det tenkes at norske aktørers habitus er med på å strukturere Norges ortodokse posisjon samt fraværet av maktkamper i det europeiske sikkerhetsfeltet. Den integrasjonsvennlige habitusen former norske aktørers forsøk på å 
fremstå som normale i sikkerhetsfeltet. Fokuset på stigma som presenteres under vil videre utdype utside/innside-problematikken i norske sikkerhetspolitiske aktørers liv.

\section{Symbolmakt}

Symbolmakten representerer på mange måter kontinuitetsfaktoren i vår sosiale væren. Som Bourdieu selv har sagt er den i stand til å «preserve or (...) transform objective principles (...) which are at work in the social world» (Bourdieu 1989: 23). Makt er relasjonelt og ulike former for makt er bundet til kontrollen av ressurser som korresponderer med, og reproduserer, ulike felt (Guzzini 2013: 80). Poenget er at ulike former for makt, eller kapital, bidrar i produksjonen av dominans. Disse ulike relasjonene definerer felters logikk og dermed også hva som blir forstått som legitimt, altså symbolmakten. Andre former for kapital som militær og vitenskapelig kapital har vært viktige i mobiliseringen rundt kontroversen om den legitime tilnærmingen til sikkerhet i Europa etter 1990 (Villumsen Berling 2015), men i konvergenspraksisen mellom Norge og EU vil det her fokuseres på symbolmakten som opererer frigjort fra individers bevisste intensjoner (Adler-Nissen 2014b: 61).

En slik tilnærming til den nye sikkerheten i Europa har også Michael C. Williams (2007: 2) tatt til orde for ved å hevde at "what took place in the 1990s was a reconfiguration of the 'field' of security where military and material power, while remaining significant, were repositioned within what might be called the 'cultural field of security' that privileged cultural and symbolic forms of power»». Williams viser hvordan maktkampen om den legitime tilnærmingen til sikkerhet i Europa etter den kalde krigen ikke ble formet av militærenes størrelser. I stedet ble det som tas for gitt i strukturerte symbolmaktforhold sentralt i aktørers posisjonering i den nye sikkerheten. Det er også her jeg vil hevde at EUs makt, styrket av norske eliters integrasjonsvennlige habitus, førte til legitimeringen av EUs makt, noe som igjen naturaliserte EUs definisjoner av Europas sikkerhetsinteresser.

\section{Stigma}

Ved å bygge på arbeidet til Erving Goffmann (1963), har Rebecca Adler-Nissen (2014a) forsøkt å vise hvordan stater er aktive aktører i sosialiseringsprosessene i det internasjonale samfunnet. Intet mellomstatlig fellesskap har bundet sine verdier sammen i felles regler og institusjoner (Bull 1977) i større grad enn EU. Det er innenfor disse institusjonelle rammene norske sikkerhetspolitiske aktører ønsker tilhørighet. Ved å anvende stigma som analytisk perspektiv på sosialiseringsprosessen i det europeiske sikkerhetsfeltet vil det fremkomme hvordan Norges posisjon utenfor den formelle integrasjonsprosessen har ført til en anerkjennelsesprosess; når avvikende oppførsel (slik som Norges posisjon «utenfor») fører til et stigma har den stigmatiserte tre valg: anerkjennelse, avvisning eller mot-stigmatisering.

Videre reagerer stater på stigmatisering kun i den grad de normene som ligger til grunn for stigmaet deles av den stigmatiserte, samt de materielle og sosiale kapabiliteter staten besitter (Adler-Nissen 2014a: 154). Når det gjelder det første er det ikke slik at den prosessen som oppsto i sikkerhetsfeltet på 1990-tallet var noe radikalt brudd med gammel praksis - Norge og EU var samstemte i 
sikkerhetspolitikken også før 1990. Den integrasjonsvennlige habitusen i Norge peker også mot et identitetsfellesskap. Hva gjelder det andre kriteriet kan små staters søken etter status være rådende (de Carvalho \& Neumann 2015). Norge er en liten stat militært og på tross av landets rikdom kan det tenkes at det ikke oppleves å være noe rom for å avvise det EU definerer som «normalt». Norge har søkt status i Europa gjennom sin tilknytning til EUs sikkerhetspolitiske arbeid (Græger 2015: 103n9), noe som kan hevdes å gjelde spesielt opp mot likesinnede stater som Sverige, Danmark og Nederland i et forsøk på å opprettholde status. Dette resonerer også med Clive Archers (2005: 79) observasjon av at norske aktører fryktet marginalisering som følge av EUs sikkerhetspolitiske integrasjon på 1990-tallet og derfor drev en aktiv politikk mot unionen.

Norge er en «outsider» i europeisk politikk og gitt forholdet mellom den integrasjonsvennlige habitusen blant landets eliter og EUs symbolmakt bør det være ukontroversielt å hevde at mange opplever sin posisjon som ukomfortabel. Det er derfor stigmatiseringsprosesser er interessante å redegjøre for i denne artikkelen sammen med Bourdieus teori. Bourdieu har selv hevdet at Goffmans arbeid fanger opp aktørers symbolske kamper gjennom «strategies of presentation of self (...) that are designed to manipulate one's self-image and especially - something Goffman overlooked - the image of one's position in social space» (Bourdieu 1989: 20). Grunnet den evigvarende søken etter status (Wohlforth 2015: 146-148) er det altså noe rasjonelt ved den norske anerkjennelsen av stigmaet som er påført av EU. Samtidig kan den hevdes å være mer konstituerende enn rasjonell, grunnet symbolmakten som opererer bortenfor norske aktørers bevissthet. Denne makten styrker også den integrasjonsvennlige habitusen i Norge og man har på mange måter en sluttet sirkel. Fokuset på stigma viser hvordan aktører er begrenset av sine egne posisjoner og at disse aktørene igjen vil anerkjenne stigmaet som blir påført dem. Det er nettopp denne prosessen som har ført til at norske «outsidere» har banet vei for en sikkerhetspolitisk konvergenspraksis mellom Norge og EU siden 1990.

\section{Europa og den nye sikkerheten}

Denne analysen har sitt empiriske startpunkt ved et historisk vannskille Sovjetunionens fall og slutten på Den kalde krigen. Uavhengig om man forsto denne endringen som historiens ende (Fukuyama 1989), USAs unipolare øyeblikk (Krauthammer 1991) eller starten på sivilisasjonenes kamp (Huntington 1993), sto vestlige politikere og beslutningstakere $\mathrm{i}$ en posisjon der de måtte redefinere sine forhold til (u)sikkerhet. Dette var intet unntak for Norge - landet delte grense med Sovjetunionen i nord og hadde et forsvar som var innrettet og trent for å forsvare landets territorium fra den røde fare i øst. Denne sikkerhetslogikken skulle bli, naturlig nok, omstridt i den fremvoksende konteksten.

Det har vært argumentert for at Norge kom sent ut av startblokkene i den nye sikkerhetskonteksten. Nina Græger (2011) har for eksempel hevdet at militærets rolle nasjonalt hadde stor betydning for det som ble en treg restrukturering av den norske sikkerhetsdiskursen. I stedet fortsatte de territorielle hensynene fra den kalde krigen 
å dominere. NATO-landene gjennomgikk dyptgripende endringer og Norge hang etter. Gitt at Norge i 1991 var et av de siste landene som aksepterte NATO-alliansens endrede strategiske konsept, synes det å være et visst grunnlag for å hevde at landet allerede under den kalde krigen var en ortodoks aktør i sikkerhetspolitikken (Sjursen 2001: 552-553). Samtidig kan det vanskelig hevdes at sikkerhetsinteresser dannes i et nasjonalt vakuum. Om definisjonen av en ny sikkerhetslogikk i Europa var det som strukturerte det europeiske sikkerhetsfeltet i den post-sovjetiske konteksten, vil det ikke være fruktbart gjøre et klart skille mellom det nasjonale og det internasjonale. Uavhengig av hvilken rolle det militære spilte $\mathrm{i}$ å holde utviklingen av den norske sikkerhetspolitikken tilbake, er det $\mathrm{i}$ en bredere relasjonell setting at man må søke forstå den endringen som kom utover på 1990-tallet.

Det er her utviklingen av EU som sikkerhetspolitisk aktør fremstår som særlig relevant for analysen. Samtidig med at den norske befolkningen for andre gang sa nei til å være med på det europeiske integrasjonsprosjektet, tok EU et steg videre i integrasjonsprosessen på det utenriks- og sikkerhetspolitiske området. Med Maastricht-traktaten i 1992 etablerte unionen et søylesystem der en av tre søyler var den felles utenriks- og sikkerhetspolitikken (FUSP). FUSP var - og er - basert på enstemmighet, men opprettelsen av en egen søyle var allikevel et utrykk for at den nye sikkerhetslogikken i Europa var av en slik art at den krevde mer samarbeid. Dette var i og for seg ikke noe nytt. Det er dog interessant, om man går ut fra at den europeiske integrasjonen skjer som følge av selvbevisste nasjonalstater (Moravscik 1998; Milward 2000), at EU tok steget og videre institusjonaliserte også denne delen av samarbeidet. Det er altså de lange linjene i integrasjonsprosessen som er interessante for utenforland som Norge, ikke smale forhandlinger innad i unionen og tilbakeslag i et tidsmessig begrenset omfang.

Opprettelsen av FUSP var likevel ikke nok til å overbevise Norge om at EU hadde utviklet den rette tilnærmingen til sikkerhet, ei heller om de var egnet som sikkerhetspolitisk aktør (Sjursen 2004: 8). Det var først da EU satte spørsmålstegn ved Vestunionen og inkorporerte dens oppgaver i krisehåndteringsmekanismene kalt Petersberg-oppgavene, at varsellampene begynte å blinke hos norske regjeringer og frykten for å bli tilsidesatt vokste frem. Da Storbritannia og Frankrike ble enige om behovet for troverdige forsvarsstyrker på et toppmøte i St. Malo i 1998, ble det enda tydeligere at EU hadde ambisjoner om å bli en sentral aktør i europeisk sikkerhetspolitikk. Utnevnelsen av en høyrepresentant for FUSP samt opprettelsen av en felles sikkerhets- og forsvarspolitikk (ESDP), bekreftet den samme utviklingen.

\section{Norge og den integrasjonsvillige habitus}

På tross av at Norge virket å innta en skeptisk posisjon $\mathrm{i}$ forhold til EUs sikkerhetspolitiske utvikling tidlig på 1990-tallet, sluttet landet seg raskt til flere av unionens initiativer. I en redegjørelse til Stortinget i 2000 uttalte utenriksminister Torbjørn Jagland at 
Vi står i dag overfor et Europa som ser atskillig annerledes ut enn for bare få år siden. EU-utvidelsen vil bidra til å utjevne de tidligere skillelinjer mellom øst og vest i Europa. Samarbeidet innad i EU blir utdypet og mer omfattende. Europa er i sterk endring. Det skaper en ny utfordring for Norge. Derfor ønsker Regjeringen å føre en aktiv og offensiv europapolitikk. Vi vil legge vekt på mulighetene de nye rammebetingelsene gir oss, og ikke bare fokusere på problemene. Også Norge har ansvar for utviklingen i Europa. Vi ønsker å være en konstruktiv bidragsyter og medspiller. Passiv tilpasning er ikke nok (Jagland 2000: 3465).

Jaglands uttalelse indikerer at Norges forhold til sikkerhet allerede i 2000 var basert på den samme logikken som motiverte endringene i EU om at «ingen enkeltland er i stand til å takle vår tids komplekse problemer på egenhånd» (EU 2003). Videre var EUs utvidelse østover blitt den sentrale europeiske praksis for å avskaffe øst-vestskillet. Her virket både NATO og EU å ha innsett hvilke nødvendige endringer som måtte til i den nye sikkerhetskonteksten før Norge, som dermed tilpasset seg EU og NATO heller enn å selv lede an.

Fremveksten av EU som sikkerhetspolitisk aktør ble i Stortinget også vurdert opp mot Norges rolle i NATO. I et svar til Jagland tok KrF-politiker og leder i utenrikskomiteen, Einar Steensnæs tak i NATO/EU-spenningen som et argument for å involvere seg mer med EU på det sikkerhetspolitiske feltet: «vår status som fullverdig medlem i NATO tilsier en tett oppfølging av ESDP fra Norges side for en best mulig tilkopling til det forsvars- og sikkerhetspolitiske samarbeidet i EU» (Steensnæs 2000: 3465). Det forelå altså et ønske om å plassere norsk sikkerhetspolitikk i en videre kontekst og i relasjon til europeiske stormakter. NATO var selvsagt et sentralt referansepunkt i denne sammenhengen, men også EU ble fremstilt som en fremvoksende, men legitim aktør. Tradisjonelt har NATOs vilje, med få unntak, i praksis alltid også vært Norges vilje i sikkerhetspolitikken. Det faktum at makt er hierarkisk ordnet i internasjonal politikk synliggiøres i Steensnæs uttalelse.

Gitt at EU var i en tidlig fase i utviklingen av sin sikkerhetspolitikk i 2000, og at denne politikken heller ikke $\mathrm{i}$ dag er fullstendig og godt koordinert, burde vår forståelse av hva som strukturerte Norges tilpasning til EU som sikkerhetspolitisk aktør gå lengre og forkaste ideen om at det kun var unionens militærmakt som ledet utviklingen av konvergenspraksisen mellom Norge og EU. EUs militærmakt er særdeles begrenset av manglende vilje til samordning. En mulig sympatisk holdning ovenfor unionens militære kapabiliteter ville være å bedømme den ut ifra dens potensiale, heller enn dens nåværende evne og vilje - da er EU en supermakt (Moravcsik 2009).

Det vi så på 1990-tallet og begynnelsen av 2000-tallet var en situasjon der EU definerte den nye sikkerhetslogikken i det europeiske sikkerhetsfeltet og Norge sakte tok innover seg den samme logikken. Et analytisk grep her ville vært å undersøke den posisjonen Norge tok opp vis-a-vis EU i den politiske maktkampen i denne perioden. Det har derimot ikke vært mye debatt om Norges sikkerhetspolitiske forhold til EU. I stedet har det utviklet seg en praksis der det kan hevdes at Norge har gått fra å være bremsekloss til å bli en samarbeidspartner (Sjursen 2008) uten kamp med EU. 
Norge har utviklet seg til å bli en ortodoks aktør som forsvarer den sikkerhetslogikken EU definerte og utviklet på 1990-tallet. Kritikk kan styrke aktørers legitimitet i politiske maktkamper, men Norges posisjon som «outsider» i det europeiske sikkerhetsfeltet kan ha hindret slik kritikk fra å fremmes ettersom det kan ha blitt opplevd som en umulig posisjon å kritisere fra. Nettopp på grunn av denne posisjonen som utenforstående har Norge paradoksalt nok vært en sterkere pådriver for pan-europeisk sikkerhetssamarbeid enn enkelte medlemsland. Et åpenbart eksempel er Danmark, som ikke er med i EUs forsvarssamarbeid. Rasjonalistiske forklaringsmodeller vil forklare dette ved å se på de empiriske realitetene som former den europeiske sikkerhetskonteksten og konkludere med at Norge har handlet $\mathrm{i}$ tråd med sine nasjonale interesser. Det relasjonelle perspektivet i denne artikkelen er derimot mer interessert $\mathrm{i}$ elitene som spiller de sentrale rollene i utformingen av Norges sikkerhetspolitikk og i den sammenheng blir det mer interessant å fokusere på hva det er som former disse elitenes tenkning omkring hva som er den rette, passende eller rasjonelle norske posisjonen i europeisk sikkerhet.

\section{Eliter og europeisk integrasjon}

Den fremvoksende konvergenspraksisen, samt Norges ortodokse posisjon i det europeiske sikkerhetsfeltet, skyldes en elitehabitus som i hovedsak er integrasjonsvennlig og som på bakgrunn av dette har plassert norske aktører i sosiale settinger der deres disposisjoner passer dårlig i sammenheng med at de representerer et land som står på utsiden av integrasjonsprosessen, rent formelt. På denne måten kan det hevdes at konvergenspolitikken er en del av hvordan norske eliter siden neiavstemningen i 1994 har svart befolkningens avslag med en form for diskret integrasjon (Toje 2010: 224). I denne sosiale settingen har Norge blitt en av de ledene protagonistene for europeisk integrasjon på sikkerhetsfeltet.

Det europeiske sikkerhetsfeltet består ikke av autonome stater som opptrer som enhetlige aktører. I stedet er det et sted der visse aktører tar visse posisjoner der de har innflytelse og evne til å påvirke politikken. Dermed er utenrikspolitikk og konstruksjonen av Norges sikkerhetspolitikk, som det alltid har vært, et elitistisk prosjekt. En sentral del i Bourdieus arbeid er nettopp fokuset på hvordan klasse reproduseres. Iver B. Neumann (2008: 674) har vist hvordan norsk diplomati også kan forstås fra et klasseperspektiv fordi klasser er relativt forankret i samfunnsstrukturene, noe som gjør at de lave inntektsforskjellene i Norge ikke utelukker et slikt perspektiv. Neumann (2003) har også forklart at den norske skepsisen mot europeisk integrasjon har blitt styrket av konstruksjonen av en identitet som baserer seg på folket, og ikke statens rolle i hva som er det norske. Det virker altså å være en tilnærming til det europeiske integrasjonsprosjektet i Norge som baserer seg på at prosjektet ikke er forenelig med ideen om det norske folket. Uavhengig av hvor problematisk dette synet er teknokratisk sett er det den motsatte ideen, den Neumann forfekter, som er mer interessant i denne artikkelens sammenheng, nemlig at EU er en «klubb» Norge burde være en del av. En studie som ble gjennomført i forkant av 1994-avstemningen fant at ja- og nei-siden var delt gjennom en sentrum-periferi-motsetning der ja-velgerne var mennesker som hadde «posisjoner $\mathrm{i}$ 
samfunnet som gir belønning og prestisje (Gleditsch \& Hellevik 1977). Dette er de som har høy utdanning, stilling og inntekt, noe som gjerne er sammenfallende med det å være mann - altså den typiske EU-tilhengeren» (Dale \& Rudlang 1994: 85).

Det har blitt omtrent aksiomatisk i den politiske diskursen i Norge å vektlegge hvor viktig det er med et bredt samarbeid med EU, også innenfor sikkerhetspolitikken. Kort sagt finner norske sikkerhetspolitiske aktører at de er enige i EUs definisjoner av, og vurderinger rundt sikkerhet. Dette kan delvis forklares med henvisning til EUs symbolske makt i relasjon til norske eliter - EUs posisjoner ble underbevisst forstått som den rette praksis i den nye sikkerhetskonteksten fordi, som Williams (2007) har argumentert for, kampen om europeisk sikkerhet ble rotfestet i kulturell kapital. Gitt norske aktørers syn på integrasjonsprosjektet var konvergensen dermed i praksis uunngåelig. Den norske Nobelkomiteen er i utgangspunktet politisk uavhengig, men den kan allikevel, gitt at den består av tidligere stortingspolitikere, eksemplifisere Norge og EUs symbolske forhold. Komiteen gav i 2012 fredsprisen til EU for hvordan unionen «gjennom mer enn seks tiår (har) bidratt til å fremme fred og forsoning, demokrati og menneskerettigheter i Europa» (Den Norske Nobelkomite 2012). Denne pristildelingen viste hvordan EUs kulturelle kapital i relasjon med mennesker i de privilegerte klasser i Norge var nært knyttet til symbolmakten EU har som sikkerhetsaktør. De tidligere topp-politikerne som satt i komiteen illustrerte dette tydelig med den kontroversielle prisen.

\section{$\AA ̊$ være en «outsider»}

Som tidligere nevnt opererer et dyptgripende stigma i Norges forhold til EU. Mange historier er blitt fortalt om hvordan norske politikere, diplomater og andre aktører må vente $\mathrm{i}$ korridoren når $\mathrm{EU}$ stenger dørene til sine møter og hvordan lobby på gatekaféer er nødvendig for å få til noe som helst i Brussel. Aktørene som institusjonelt sett utformer Norges sikkerhetspolitikk står utenfor dørene når mye av grunnlaget for norsk sikkerhetspolitikk legges. Det er kanskje også derfor noen benyttet anledningen da nei-siden feiret 20-årsjubileet til folkeavstemningen i 1994 til å peke på at EØS-avtalen har gitt Norge mindre selvbestemmelsesrett (Eriksen 2014). Utviklingen i sikkerhetspolitikken viser at dette også strekker seg utover det Norge gikk med på 1994 .

Norge befinner seg utenfor EUs institusjoner, men de integrasjonsvillige tilbøyelighetene til norske eliter og EUs overtak gjennom sin symbolske makt giør at konvergenspraksisen ikke bør forstås som en frivillig sosialiseringsprosess fra Norges side. I stedet er det snakk om sosialisering gjennom stigmatisering (Zarakol 2014) som har ført til Norges integrasjonsvillighet med EU i sikkerhetspolitikken.

Forståelsen av Norge som en «outsider» i Europa kan naturlig nok ikke begrenses til det sikkerhetspolitiske feltet. Bildet giennomsyrer Norge som stat $\mathrm{i}$ Europa og sikkerhetsdimensjonen i denne analysen er bare et av flere områder denne oppfatningen av Norge dominerer relasjonene med EU. Høyres Nicolai Astrup har oppsummert Norges rolle som den andre ved å peke på at «om du vil styre Europa, må du være i Europa. Om du vil bli styrt av Europa, bli gjerne med Norge i EØS» 
(sitert i Bounadonna 2015). Det er altså en forståelse av selvet i norsk politikk som baserer seg på en opplevd skam knyttet til det å stå utenfor.

\section{Anerkjennelse av stigma}

Aktører kan oppleve at stigmaet de er påført er berettiget dersom de deler de samme normative synene på normal oppførsel som de som påfører stigmaet. Når den påførende parts moralske autoritet blir anerkjent, vil den som er gjort til skamme forsøke å handle slik at den kan bli en del av den «siviliserte gruppen» som påførte stigmaet (Adler-Nissen 2014: 154). I et forsøk på å gi disse teoretiske betraktningene som stammer fra sosiologen Erving Goffman mening, virker eksempelet med Norges sikkerhetspolitiske forhold til EU å være særdeles treffende.

Grunnet det strukturerende forholdet mellom EUs symbolmakt i relasjonen til Norge og norske aktørers integrasjonsvennlige habitus som har ført til Norges ortodokse posisjon i det europeiske sikkerhetsfeltet, blir rasjonalistiske forklaringer av konvergenspraksisen vanskelige å motsi. Disse aktørene opplever at Norges sikkerhetsinteresser er EUs sikkerhetsinteresser og vice versa. På den måten fremstår det som rett å søke samarbeid på et bredere nivå enn det nasjonale. I Norges tilfelle stammer disse betraktningene fra en identitetskonstruksjon som baserer seg på stigmatiseringsprosesser som kommer før de politiske begrunnelser som ofte tolkes som rasjonelle og nyttemaksimerende. Norges posisjon som en «outsider» i forholdet til det mer «normale» EU, kommer godt frem i det følgende utsagnet fra statsminister Erna Solberg i en kommentar til debatten om Storbritannias fremtid i EU:

Both EU member states and those of us who are «outsiders» need to become better at communicating the positive narrative of Europe. The EU works best when it works together to solve the issues at hand, whether it is brokering peace, helping poor countries develop, through climate negotiations or in trade rounds. I believe that the countries in the «inner 27 » and those of us in the «outer 4 » share the values and principles of freedom, responsibility and diversity. Consequently, we need to strive for the closest possible cooperation when seeking to preserve those values and principles (Solberg 2014).

Statsministerens forsvar av det nære samarbeidet med EU vektlegger likhetene mellom det «indre» og «ytre» Europa. Hun forstår altså Europa som bestående av en kjerne og en periferi, der EU er kjernen og Norge befinner seg i periferien. På dette punktet er hun videre klar på at det er viktig for Norge å nedtone denne annerledesheten fordi Norge også er «normal» - Norge føler, ser ut som og oppfører seg som et EU-land. Solbergs uttalelse er et klart eksempel på stigma-anerkjennelse. Hun forteller publikum at EU ikke behøver å se Norge som en «outsider», og at Norge er et normalt land, i harmoni med EU, aktøren som definerer den passende praksis. «Naturligheten» i Norges relasjon til EU slik Solberg forklarer at det er en tilstand av harmoni, skjuler maktforholdet som ligger i forholdet mellom de to.

Tidligere Europaminister Vidar Helgesen kastet seg også inn i den britiske EU-debatten. Ifølge Helgesen er det i både det norske og det britiske folk en interesse av at sistnevnte holder seg innenfor unionen (sitert i Helm 2015). Om vi vender tilbake til anomalien som ble påpekt innledningsvis i denne artikkelen, at Norge er et 
selvvalgt ikke-medlem men likevel deltar aktivt i EUs sikkerhetspolitikk, kan det stilles spørsmål ved hvorfor statsråden inntok rollen som EU-kommisjonær med mål om å overbevise den britiske befolkningen om å bli med videre $\mathrm{i}$ det europeiske integrasjonsprosjektet. Dette er imidlertid akkurat den type uttalelse man kan forvente av en stigmatisert aktør som anerkjenner stigmaet. I Europa, i hvert fall i de politiske kretser sentrert rundt Brussel, er normen å snakke på vegne av en bestemt måte å være og å løse problemer. Problemer skal løses innenfor rammen av de etablerte institusjonene i EU. Helgesen ser bort fra makten i Brussel som er anerkjent og problematisert i den britiske debatten, og i stedet behandler han den makten som en form for væren. Som i eksempelet med statsministeren ovenfor, ledet stigma-anerkjennelsen Europaministeren til å naturalisere de maktforholdene som bidrar til å strukturere Norges konvergenspraksis med EU.

Det er en vanlig oppfatning at Norge som oftest deler sikkerhetspolitiske utfordringer med EU (Utenriksdepartementet 2001). Dette er også det dominerende narrativ når norske myndigheter rettferdiggjør den sikkerhetspolitiske konvergensen. Utenriksminister Brende uttalte i forbindelse med sanksjonene mot Russland at «helt siden begynnelsen av krisen i Ukraina har Norge stått sammen med EU, USA og andre likesinnede land i reaksjonene mot Russlands brudd på folkeretten» (Brende 2015). Den rasjonelle årsaken til at Norge er med i sanksjonsregimet blir altså forsvart gjennom å peke på viktigheten av felles identitet samt hvordan Norge for Brende deler sinn med sine mektige allierte. I forhold til EU derimot, ser ikke Norge helt likt ut fordi landet ikke er medlem. På tross av nei-avstemningen i 1994, har restruktureringen av den europeiske sikkerhetslogikken vært preget av et Norge som følger etter EU fordi det forstås som det rette å gjøre på bakgrunn av felles verdier, interesser og former for væren. Praksisen blir begrunnet i felles ideer og binder Norge til EUs strategiske interesser og anerkjennelse som en global aktør for eksempel vis-avis Russland. Igjen, maktforholdene som er involvert blir ikke anerkjent, eller misforstått, som en konsekvens av anerkjennelsen av stigmaet Norge er påført i det europeiske sikkerhetsfeltet.

I kjølvannet av Sovjetunionens fall og Europas fremvoksende behov for å redefinere sitt forhold til (u)sikkerhet, har det vokst frem en konvergenspraksis mellom Norge og EU i sikkerhetsfeltet. Denne konvergensen skyldes at makten som ligger i Brussel til å definere hva som skal være den legitime tilnærmingen til sikkerhet i det post-Sovjetiske Europa, har blitt anerkjent som legitim fra et norsk standpunkt. Dette skyldes at de aktørene som har representert Norge i sikkerhetspolitikken har hatt en integrasjonsvennlig habitus - de ønsker å se Norge som en del av EU. Videre er det slik at $\mathrm{i}$ et felt der norske aktører har blitt konfrontert med et stigma som «outsider», har responsen grunnet ønsket om å bli sett på som normal vært anerkjenne EUs makt og vurderinger som passende praksis. Historien om denne konvergenspraksisen har krevd at analysen har måttet gå lengre enn tradisjonelle analysetilnærminger til utenrikspolitikk der stater hevdes å være rasjonelle og frigjort fra individers liv. I den slags tilnærminger gis aktørers handlinger mening gjennom å evaluere dem på bakgrunn av deres egne vurderinger av konsekvenser, det passende, samt gjennom meningsutveksling. Denne artikkelen har bygget på sosialteori og 
introdusert en relasjonell tilnærming som er interessert $\mathrm{i}$ hvordan tenkningen omkring hva som er passende, rett eller de mulige konsekvensene av handlinger blir formet. Denne tilnærmingen har muliggjort en analyse av hierarkiet i europeisk politikk. Innenfor rasjonalistiske forståelsesrammer blir dette hierarkiet oftest oversett grunnet de handlingslogikkene som regjerer der. Stigmatiseringsprosesser som den som har ført til Norges sosialisering i Europa, er et uttrykk for hvordan aktører instrumentelt sett søker innflytelse. Allikevel har det relasjonelle fokuset på symbolmakt og habitus styrket analysen grunnet vektleggingen av kost-nyttevurderingers begrensede evne til å øke vår forståelse av hvorfor konvergenspraksisen mellom Norge og EU har oppstått.

\section{Konklusjon}

Globalisering har gjort at den internasjonale arenaen $\mathrm{i}$ økende grad har blitt et intersubjektivt rom, og stater er intet unntak i denne sammenhengen. Staters interesser er ikke stillestående og upåvirkelige, men sosialt forankret og utsettes for endrede definisjoner over tid. Hendelser som den kalde krigens avslutning bidrar til staters redefinering av (u)sikkerhet. Også behov for status og anerkjennelse er med på å påvirke staters handlinger. Aktører i det europeiske sikkerhetsfeltet, og andre felter for den saks skyld, ønsker å fremstå som «normale» og denne dynamikken sørger for at kontinuitet preger internasjonal politikk. Når selve definisjonen av hva som skulle være den legitime tilnærmingen til sikkerhet ble gjenstand for symbolske maktkamper etter Sovjetunionens fall, kom det også tydelig frem hvordan europeisk politikk er hierarkisk ordnet.

Denne artikkelen har vist hvordan Norge som et lite land i denne maktkampen styres av aktører som aldri egentlig gikk inn i maktkampen om den legitime definisjonen av sikkerhetspolitikken i Europa. I stedet inntok Norge en ortodoks posisjon der landet lærte av EU hvordan man burde forholde seg til u(sikkerhet) i den nye sikkerhetspolitiske konteksten. Det er fra denne ortodokse posisjonen at praksisen med å slutte seg til og følge EUs vurderinger utviklet seg. Den foregående analysen av denne praksisen begynte med en vektlegging av hvordan norske aktører i sikkerhetspolitikken skiller seg fra sine mandatsgivende velgere gjennom en integrasjonsvennlig habitus - pro-EU disposisjoner som gjør det ubehagelig å representere Norge i sosiale settinger der de er nødt til å representere en «outsider». Elitene som har utviklet norsk sikkerhetspolitikk siden 1990 ønsker ikke å stå utenfor EU og de har derfor respondert på posisjonen som «outsider» ved å oppføre seg som om Norge var medlem i EU.

I forklaringen av dette ble stigmatiseringsprosesser behandlet som sentrale $\mathrm{i}$ sosialiseringsprosesser i internasjonal politikk. Det er blitt vist hvordan norske aktører har forsvart sine politiske grep ved å vektlegge hvordan det var den normale handling fordi EU gjorde det samme. Norske aktører har altså anerkjent makten i Brussel som legitim. EU er ikke en stat, men når unionens medlemmer klarer å enes om felles sikkerhetspolitikk er organisasjonen i en posisjon til å avgjøre hvordan utenforland som Norge må handle for å bli sosialt akseptert. EU setter på mange 
måter standarden. Den egenskapen har i denne artikkelen blitt diskutert i lys av et norsk statsapparat som befinner seg $\mathrm{i}$ en skvis mellom sin elitehabitus og nasjonalistiske disposisjoner.

Konvergenspraksisen mellom Norge og EU har manifestert seg i europeisk politikk siden 1990 og denne artikkelen er skrevet basert på et ønske om å forstå denne utviklingen fra et sosial-teoretisk ståsted. EU-linjen og de praksisene som er vist til her begrenser seg ikke til sikkerhetspolitikken og det er et stort rom for å anvende sosiale-teoretiske metoder i videre studier av Norges forhold til EU, både innenfor og utenfor EØS-avtalens rammeverk. Det ligger utvilsomt et potensiale i å utforske hvilke norske aktører som leder utviklingen av konvergenspraksisen samt hvordan EUs symbolmakt og evne til å definere det «normale» blir instrumentelt anvendt i internasjonal politikk.

Den relasjonelle tilnærmingen som er anvendt i denne artikkelen og som fokuserer på hvordan felter blir strukturert og den sosiale dynamikken i disse feltene har bidratt til et narrativ om et EU som i stor grad leder Norges sikkerhetspolitiske utvikling. Sanksjonsregimet mot Russland illustrerer begrensningen av en rasjonalitetstekning som vektlegger kost-nytte-kalkyler av økonomisk sort, i tillegg til hvordan det å stå utenfor EU i dette tilfellet kunne vært brukt til Norges fordel. Norge kunne ekspressivt støttet sanksjonene mot Russland uten å implementere dem. På den måten kunne de store tapene i eksportavhengige industrier slik som fiskeriet sluppet de økonomiske utfordringene som fulgte med sanksjonene. Men, som denne artikkelen har vist, og som utenriksministerBrende også var klar på, det var aldri noe tema å ikke følge EU i dette spørsmålet fordi det hører med til tradisjonen å gjøre det. Kostnadene sanksjonene medførte var ikke av betydning $\mathrm{i}$ prosessen og det kan derfor også stilles spørsmål ved rasjonalistiske tilnærmingers evne til å universelt forklare sosiale handlinger.

EU-debatten er i dag så godt som fraværende i Norge. Oppslutningen for medlemskap er $\operatorname{lav}^{2}$ og integrasjonsforkjemperne ser små muligheter til å snu den trenden i umiddelbar fremtid. I tillegg befinner EU seg i en stadig voksende krise som $\mathrm{i}$ økende grad handler om dens egen eksistens $\mathrm{i}$ fremtiden. I et mindre enn lunkent EU-klima her til lands virker det derfor i stedet som at integrasjonsvillige krefter tar sikte på å bruke deres posisjoner til å utvikle et de facto medlemskap i unionen. I denne utviklingen ligger det et dypt demokratisk problem så lenge praksiser som den sikkerhetspolitiske konvergensen med EU forsetter. Integrasjonskreftene bør i første omgang vende seg til den norske offentligheten, deretter til Brussel. Det finnes overbevisende grunner til at Norge ikke kan eksistere i isolasjon $i$ en verden og et Europa som i økende grad blir bundet sammen. Dette gjelder også i sikkerhetspolitikken, men folkelig støtte for retningen som stakes ut vil være uunnværlig i det lange løp.

\footnotetext{
${ }^{2}$ I en meningsmåling gjennomført i desember 2015 var nei-siden over 70 prosent, mens kun 18 prosent av de spurte var for EU-medlemskap (Dagens Næringsliv 2015).
} 


\section{Om artikkelen}

En stor takk til IPs redaktører og til komitéen som tildelte denne artikkelen Ordingprisen for 2015. Takk rettes også til Iver B. Neumann for stødig veiledning samt til Kirsti Stuvøy og Sindre Viksand for innsiktsfulle kommentarer underveis i prosessen.

\section{Litteraturliste}

Adler-Nissen, Rebecca (2013) Bourdieu in International Relations. New York: Routledge.

Adler-Nissen, Rebecca (2014a) «Stigma Management in International Relations: Transgressive Identities, Norms, and Order in International Society», International Organization, 68 (1): 143-176.

Adler-Nissen, Rebecca (2014b) «Symbolic power in European diplomacy: the struggle between national foreign services and the EU's External Action Service», Review of International Studies, 40 (4): 657-681.

Adler-Nissen, Rebecca (2016) «Towards a Practice Turn in EU Studies: The Everyday of European Integration», Fournal of Common Market Studies, 54 (1): 87-103.

Adler, Emmanuelle \& Michael Barnett (1998) Security Communities. Cambridge: Cambridge University Press. Adler, Emmanuelle \& Vincent Pouliot (2011) International Practices. Cambridge: Cambridge University Press. Archer, Clive (2005) Norway outside the European Union. London: Routledge.

Axelrod, Reohane \& O. Kobert Robert (1985) «Achieving Cooperation under Anarchy: Strategies and Institutions», World Politics, 38 (1): 226-254.

Bigo, Didier \& R.B.J. Walker (2007) «Political Sociology and the Problem of the International», Millennium, 35 (3): $725-739$.

Bourdieu, Pierre (1984) Distinction. Cambridge, Mass.: Harvard University Press.

Bourdieu, Pierre (1989) «Social Space and Symbolic Power», Sociological Theory, 7 (1): 14-25.

Bourdieu, Pierre (1990) The Logic of Practice. Stanford, Calif.: Stanford University Press.

Brende, Børge (2015) Utenrikspolitisk redegjørelse 5. mars 2015. Tilgjengelig på https://www.regjeringen.no/ no/aktuelt/redegjorelse_150305/id2398550/. Lesedato 06.07.2015.

Bull, Hedley (1977) The Anarchical Society. New York: Columbia University Press.

Buonadonna, Paola (2015) Press Release: «Norway? No way. Influence, power and status would be damaged by Brexit, experts’ briefing shows.» Tilgjengelig på http://www.britishinfluence.org/press_release_norway_ no_way. Lesedato 19.08.2015.

Buzan, Barry, Ole Wæver \& Jaap de Wilde (1998) Security. A New Framework for Analysis. London: Lynne Rienner.

Carvalho, Benjamin de \& Iver B. Neumann (2015) Small State Status Seeking. Abingdon, Oxon: Routledge.

Dagbladet (2014) «Børge Brende: - Norge innfører EUs sanksjoner mot Russland». Tilgjengelig på http://www. dagbladet.no/2014/03/17/nyheter/krig_og_konflikter/eu/politikk/32354762/. Lesedato 15.01.2015.

Dale, Trine \& Hilde Rudlang (1994) «Hvem mener hva i EU-saken?» Tilgjengelig på http://ssb.no/valg/artiklerog-publikasjoner/_attachment/69778?_ts=137dac69360. Lesedato 06.07.2015.

Den Norske Nobelkomite (2012) Kunngjøring. Nobels Fredspris for 2012. Tilgjengelig på http://nobelpeaceprize.org/nb_NO/laureates/laureates-2012/announce-2012/. Lesedato 09.12.2015.

DiMaggio, Paul (1979) Review Essay: «On Pierre Bourdieu», The American fournal of Sociology, 84 (6): 14601474 .

Dagens Næringsliv (2015) «Bare 18 prosent sier ja til EU». Tilgjengelig på http://www.dn.no/nyheter/ politikkSamfunn/2015/12/30/0520/bare-18-prosent-sier-ja-til-eu. Lesedato 28.01.2016.

Doyle, Michael W. (1986) «Liberalism and World Politics», The American Political Science Review, 80 (4): 1151-1169.

Eriksen, Erik O. (2014) «Norway's rejection of EU membership has given the country less self- determination, not more», Tilgjengelig på http://blogs.lse.ac.uk/europpblog/2014/04/22/norways-rejection-of-eu-membership-has- given-the-country-less-self-determination-not-more/. Lesedato 09.02.2015.

Eriksson, Johan (1999) «Observers or Advocates?: On the Political Role of Security Analysts», Cooperation and Conflict, 34 (3): 311-330.

EU (2003) «A Secure Europe in a Better World». Tilgjengelig på http://www.consilium.europa.eu/uedocs/ cmsUpload/78367.pdf. Lesedato 5.5.2014.

Fukuyama, Francis (1992) The End of History and the Last Man. New York: Free Press. 


\section{Stigma $i$ internasjonal politikk}

Goffman, Erving (1963) Stigma: Notes on the management of spoiled identity. Englewood Cliffs, N.J.: PrenticeHall.

Goldstein, Judith \& Robert O. Keohane (1993) Ideas and Foreign Policy. Ithaca: Cornell University Press.

Græger, Nina (2011) "'Home and away'? Internationalism and territory in the post-1990 Norwegian defence discourse», Cooperation and Conflict, 46 (1): 3-20.

Græger, Nina (2015) «From 'forces for good' to 'forces for status'? Small state military status seeking», i B. Carvalho \& I. B. Neumann (red.) Small State Status Seeking. Adbigdon, Oxon: Routledge (86-107).

Guzzini, Stefano (2000) «A Reconstruction of Constructivism in International Relations», European fournal of International Relations, 6 (2): 147-182.

Guzzini Stefano (2013) Power. I R. Adler-Nissen (red.) Bourdieu in International Relations. New York: Routledge (78-92).

Hansen, Lene (2000) «The Little Mermaid's Silent Security Dilemma and the Absence of Gender in the Copenhagen School», Millennium, 29 (2): 285-306.

Helm, Toby (2015) «Britain will lose influence in the world if it quits the EU, says Norway». Tilgjengelig på http:/www.theguardian.com/politics/2015/feb/22/norway-urges-uk-dont-leave-eu. Lesedato 06.07.2015.

Huntington, Samuel P. (1993) «The Clash of Civilizations?», Foreign Affairs, 72 (3): 22-49.

Jagland, Torbjørn (2000) Redegjørelse av utenriksministeren om Norges forhold til EUs sikkerhets- og forsvarssamarbeid (ESDP). Tilgjengelig på https://www.stortinget.no/no/Saker-og-publikasjoner/Publikasjoner/Referater/Stortinget/1999-2000/000609/1/\#a1. Lesedato 29.06.2015.

Keohane Robert, O. \& Joseph S. Nye (1977) Power and Interdependence. Boston: Little, Brown.

Krauthammer, Charles (1990) «The Unipolar Moment», Foreign Affairs, 70 (1): 23-33.

Leander, Anna (2008) «Thinking tools» i A. Klotz \& D. Prakash (red.) Qualitative Methods in International Relations. London: Palgrave Macmillan (11-27).

Manners, Ian (2002) «Normative Power Europe: A Contradiction in Terms?», fournal of Common Market Studies, 40 (2): 235-258.

March, James G. \& Johan P. Olsen (1998) «The Institutional Dynamics of International Political Orders», International Organization, 52 (4): 943-969.

Mérand, Frédéric (2010) «Pierre Bourdieu and the Birth of European Defense», Security Studies, 19 (2): 342-374.

Milward, Alan (2000) The European Rescue of the Nation-State. London: Routledge.

Moravcsik, Andrew (1998) The Choice for Europe. Ithaca, N.Y.: Cornell University Press.

Moravcsik, Andrew (2009) «Europe: The quiet superpower», French Politics, 7 (3-4): 403-422.

Neumann, Iver B. (2001) «This Little Piggy Stayed at Home: Why Norway is not a Member of the EU» $\mathrm{i}$ L. Hansen \& O. Wæver (red.) European Integration and National Identity. London: Routledge (88-129).

Neumann, Iver B. (2002) «Returning Practice to the Linguistic Turn: The Case of Diplomacy», Millennium, 31 (3): $627-651$.

Neumann, Iver B. (2008) «The Body of the Diplomat», European fournal of International Relations, 14 (4): 671-695.

NOU 2012:5 «Utenfor og innenfor. Norges avtaler med EU», Tilgjengelig på https://www.regjeringen. no/contentassets/5d3982d042a2472eb1b20639cd8b2341/no/pdpd/nou201220120002000dddpdfs.pdf. Lesedato 29.1.2016.

Pouliot, Vincent (2008) «The logic of Practicality: a theory of practice of security communities», International Organization, 62 (2): 257-288.

Rieker, Pernille (2004) «Europeanisation of Nordic Security? The EU and the changing security identities of the Nordic States», Cooperation and Conflict, 39: 369-392.

Rieker, Pernille (2006) «Norway and the ESDP: Explaining Norwegian Participation in the EU's Security Policy», European Security, 15 (3): 281-298.

Risse, Thomas (2000) “"Let's Argue!”: Communicative Action in World Politics», International Organization, 54 (1): 1-39.

Sjursen, Helene (2001) «Coping - or not Coping - with Change: Norway in European Security», European Foreign Affairs Review, 5: 539-559.

Sjursen, Helene (2004) «Staying Close Yet Keeping a Distance: Norway and the CFSP», CFSP Forum, $2(4): 7-9$

Sjursen, Helene (2008) «Fra bremsekloss til medløper: Norge i EUs utenriks- og sikkerhetspolitikk», Nytt Norsk Tidsskrift, 25 (4):323-332.

Sjursen, Helene (2015) «Enighet for enhver pris? Om legitimitetsgrunnlaget for norsk utenrikspolitikk», Nytt Norsk Tidsskrift, 32 (3): 219-232. 


\section{Øyvind Svendsen}

Solberg, Erna (2014) «The 'Norwegian model' would be a poor alternative to EU membership for the UK». Tilgjengelig på http://blogs.lse.ac.uk/europpblog/2013/04/19/norwegian-model-poor-alternative-eu-ukmembership-eea-erna-solberg/. Lesedato 16.06.2015.

Steensnæs, Einar (2000) Redegjørelse av utenriksministeren om Norges forhold til EUs sikkerhets- og forsvarssamarbeid (ESDP). Tilgjengelig på https://www.stortinget.no/no/Saker-og-publikasjoner/ Publikasjoner/Referater/Stortinget/1999-2000/000609/1/\#a1. Lesedato 29.06.2015.

Stuvøy, Kirsti (2009) Security under construction: a Bourdieusian approach to non-state crisis centres in northwest Russia. PhD-dissertation, The University Tromsø.

Stuvøy, Kirsti (2010) «Symbolic Power and (In)Security: The Marginalization of Women's Security in Northwest Russia», International Political Sociology, 4 (4): 401-418.

Sverdrup, Ulf (2014) «Norske sanksjoner?» Tilgjengelig på http:/www.nupi.no/Publikasjoner/Nyheter/ Norske-sanksjoner. Lesedato 15.12.2015.

Swartz, David (2008) «Bringing Bourdieu's master concepts into organizational analysis», Theory and Society, 37 (1): 45-52.

Toje, Asle (2010) «Norsk utenrikspolitikk - en kritikk», Nytt Norsk Tidsskrift, 27 (1-2): 206-217.

Utenriksdepartementet (2001) Om Norge og Europa ved inngangen til et nytt århundre. St.meld. nr. 12 (2000-2001). Oslo: Utenriksdepartementet.

Villumsen Berling, Trine (2012) «Bourdieu, International Relations, and European Security», Theory and Society, 41: 541-478.

Villumsen Berling, Trine (2015) The International Political Sociology of Security. London and New York: Routledge.

Walt, Stephen M. (1991) «The Renaissance of Security Studies», International Studies Quarterly, 35 (2): 211-239.

Waltz, Kenneth (1979) Theory of International Politics. Reading, Mass.: Addison-Wesley Pub. Co.

Wendt, Alexander (1987) «The Agent-Structure Problem in International Relations Theory», International Organization, 41 (3): 335-370.

Wendt, Alexander (1992) "Anarchy is what States Make of it: the Social Construction of Power Politics», International Organization, 46 (2): 391-421.

Wendt, Alexander (1999) Social Theory of International Politics. Cambridge, U.K.: Cambridge University Press.

Williams, Michael C. (2007) Culture and Security. Symbolic power and the politics of international security. London and New York: Routledge.

Wohlforth, William C. (2015) «Conclusion. A small middle power» i B. Carvalho \& I. B. Neumann (red.) Small State Status Seeking. Adbigdon, Oxon: Routledge (146-155).

Wæver, Ole (1995) «Securitization and Desecuritization» i R.D. Lipschutz (red.) On Security. New York: Columbia University Press (46-86).

Zarakol, Ayse (2014) «What made the modern world hang together: socialisation or stigmatisation?», International Theory, 6 (2): 311-332. 